\title{
Te Hā Whakawairua, Whakatinana i Te Mātauranga Māori i Te Whare Wānanga: The Validation of Indigenous Knowledge within the University Academy
}

\section{Preamble}

Departments and Schools of Māori Studies in New Zealand universities face a constant threat of being assimilated, or even of being disestablished. ${ }^{1}$ The persistence of lingering prejudices also means that staff in such entities feel that their disciplines and knowledge are not accorded respect within the university academy. As a result, Faculties/ Schools/ Departments of Māori Studies run the risk of being unable to fulfil their potential role in the academic world as centres for researching and teaching Indigenous knowledge for the benefit of the whole institution at the very time that the New Zealand Government, in its Tertiary Education Policy, is signalling a need to achieve greater participation of Māori in tertiary education. Given the Treaty of Waitangi ${ }^{2}$ and the status of Māori as the Indigenes of Aotearoa/New Zealand, it is proposed that the right of Departments and Schools of Māori Studies to have a distinctive character and special status within the University be acknowledged, and that provision be made for it to have an acknowledged role within the University as a repository of knowledge of kaupapa Māori ${ }^{3}$ and te reo me ngā tikanga Māori (Māori language and Māori customary lore). This would be an act of reciprocity, given that universities, in measuring the institutions' responsiveness to Māori within the sector, use the very existence of Māori Studies departments in universities and the work the staff do in these departments and across each university. Through a case-study ${ }^{4}$ approach, this essay will outline the contribution that Māori Studies departments make to universities. It will argue that it is time

Tania Ka'ai is Professor in Māori Innovation and Development at Te Ara Poutama, AUT University's Faculty of Maori Development. 
within the University Academy

that these departments received formal recognition, appropriate resources and support for this function to ensure stability and continued development within the academy in meeting the needs of the staff and students of the university and the communities (both domestic and international) that they serve.

This paper will posit that there are commonalities amongst Indigenous peoples such as Māori, Hawaiian and Aboriginal people of North America. This being the case, this paper will propose that in order for Departments, Schools and Faculties of Māori Studies, Native Studies/Aboriginal Studies and Hawaiian Studies to fulfil the central role in the university that they should have, they need to be resourced adequately to undertake research informed teaching and quality research that will contribute to the development of our respective nations and their peoples. Te Tumu already finds itself acting in this capacity for the University of Otago, but it too requires formal recognition, appropriate resources and support for this function to ensure stability and continued development within the academy in meeting the needs of the staff and students of the University and the communities (both domestic and international) that it serves. This article is aimed at enlightening the university academy by articulating the duality of functions and responsibilities upon Indigenous academics within these academies. It is hoped that it will provide a useful resource for Indigenous academics who might be facing similar circumstances

\section{Defining Māori Studies}

Māori Studies, as an academic discipline within the universities of Aotearoa/New Zealand, have usually emerged out of Anthropology, and the emergence of Pacific Island Studies has followed a similar genesis. ${ }^{5}$ However, these disciplines have had to fight for legitimacy, space and resources within the academy since they emerged. All such Departments and Schools exist with the knowledge and fear that they might be closed or assimilated, particularly into Departments such as Education. It is therefore proposed that Māori and Pacific Departments or Schools and perhaps Native Studies beyond the shores of Aotearoa/New Zealand, are sites of struggle and resistance from either further attempts at assimilation from within the academy or eradication by the 
dominant society and even the Crown. Ka'ai' 6 has defined Māori Studies as a space for undertaking teaching and research which recovers Māori histories, reclaims Māori lands and resources, restores justice and preserves Māori language and traditions within a culturally specific framework called kaupapa Māori. Herein lie the theories generated by Indigenous scholars and tohunga (experts) who have constructed models to explain a Māori way of thinking (epistemology) and a Māori way of doing things within the western academy. ${ }^{7}$

\section{Defining kaupapa Māori ideology}

Many scholars have tried to define kaupapa Māori. Leonie Pihama ${ }^{8}$ states that:

Kaupapa Māori theory is a politicising agent that acts as a counter hegemonic force to promote the conscientisation of Māori people, through a process of critiqueing [sic] Pākehā definitions and constructions of Māori people and asserting succinctly and explicitly, the validation and legitimisation of te reo me ngā tikanga Māori.

This definition is framed in post-colonial theory in that it relies on Māori critiquing Pākehā (non-Māori) definitions and constructions of Māori people and presupposes that Māori are on the margins or periphery as the 'Other'. The difficulty with this is that Māori are located in an inferior or subordinate position to the dominant majority culture. Furthermore, this definition perpetuates the assimilationist policies of the early colonists designed to push Māori to the periphery, which has had the effect of causing them to feel like dispossessed people in their own land. This approach to kaupapa Māori is commonly used by Māori educationalists to challenge policymakers about the way education has been structured in New Zealand which advantages the dominant culture and marginalises Māori, particularly their colleagues within Māori Studies departments who conceptualise kaupapa Māori from a language and culture base.

However, as Rawinia Higgins has stated, from a pure Māori Studies perspective, the term kaupapa Māori means the 'groundwork' or the 'medium' from which Māori knowledge, including te reo me ngā tikanga Māori, can be validated. ${ }^{9}$ 

within the University Academy

Kaupapa Māori paradigms develop values, actions, customs and reflections of realities that are intrinsic to Māori identity. ${ }^{10}$

Kaupapa Māori is therefore best understood as a culturally specific framework. It is located in te ao Māori (the Māori world) and reflects the relationship Māori have to the land and the environment, to Māori socialisation patterns and cultural nuances and to Māori identity. It is a framework which is best understood by other Indigenous peoples, as it corresponds philosophically with what underpins Indigenous peoples in colonized contexts, that is, their struggle for self-determination and the right to have their voices heard as they constantly fight against the disadvantaging consequences of the colonial legacy. It is kaupapa Māori that underpins the management, core business, direction and practices of Māori Studies departments to the pulse of whakatepea te kō (leadership which unites the people and focuses them on achieving the tasks at hand in a strategic way which benefits the collective and not simply the individual).

It is difficult for non-Māori to fully comprehend the concept of kaupapa Māori because they sit outside the Māori culture. Therefore, non-Māori are only able to interpret the culture through their own cultural lens and filters. This is invariably problematic for Māori within the academy and particularly Māori Studies staff, as distortions of interpretation can occur which often cause conflict between Māori and nonMāori. This happens because the culture of the university is traditionally and historically Pākehā in its design and hegemony.

Hegemony operates to subvert [Maori] knowledge and our attempts at autonomy, because the supremacy of the dominant group manifests itself in two ways; the first is as domination and the second is as intellectual and moral leadership. ${ }^{11}$

In the first instance, hegemony occurs when the dominant group establishes their world-view as "universal". This situation has certainly been the case within the education system, as the dominant culture reflected in Universities have established themselves as the norm against which every other tertiary institution is compared [including Wānanga which have been established as Māori institutions]. ${ }^{12}$

Kaupapa Māori ideology is a philosophical doctrine, incorporating the knowledge, skills, attitudes and values of Māori society that have emanated from a Māori metaphysical base. It informs Māori about the way in which they best 


$$
\text { within the University Academy }
$$

develop physically, spiritually, emotionally, socially and intellectually as a people. One of the most effective ways to understand kaupapa Māori ideology is through a model developed by the late John Te Rangiāniwaniwa Rangihau, who was highly regarded by both Māori and non-Māori.

\section{Understanding the Rangihau Model}

Figure 1: Rangihau's Conceptual Model

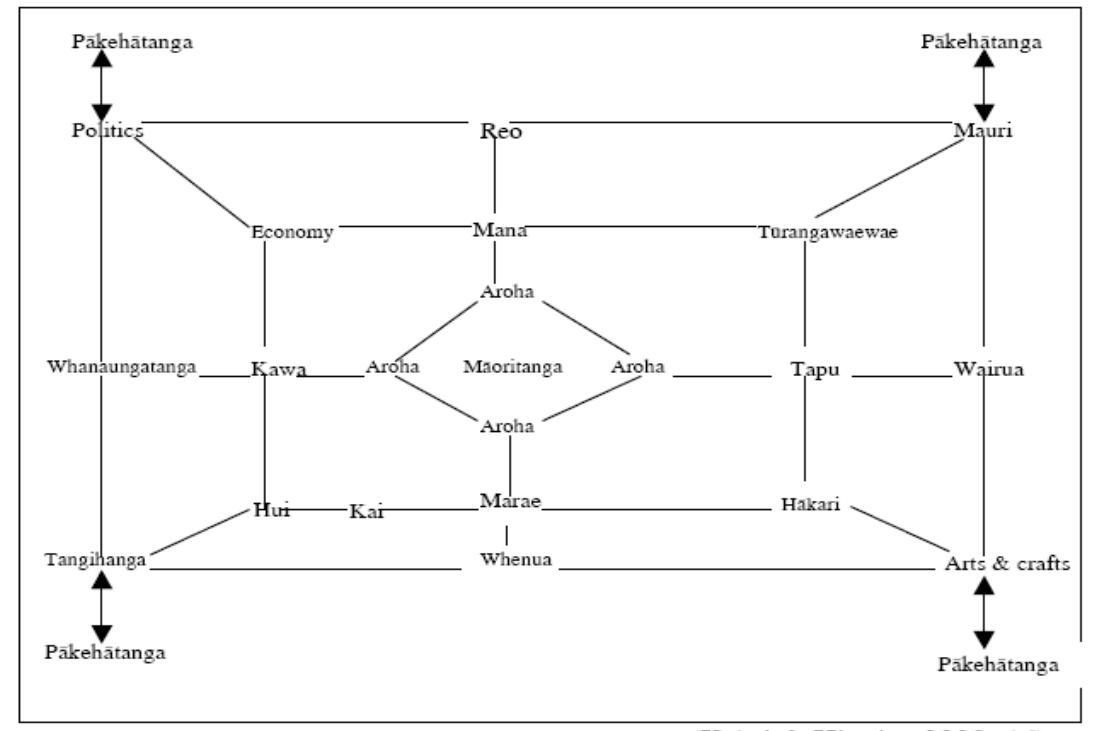

(Ka`ai \& Higgins 2003: 16)

John Rangihau was a repository of Māori knowledge respected by iwi and by Pākehā (non-Indigenous New Zealanders) policy-makers and politicians. He locates te ao Māori (the Māori world) in the centre of his model/framework under the term Māoritanga, thus enabling the Māori academic, administrator or student to locate their teaching, assessment and curriculum, supervision and research, and management systems and procedures from within this framework. Māoritanga was a term that was popularised in the 1970s through educational reform policies and the like. He locates the Pākehā world (Pākehātanga) on the periphery of the framework, thus depicting an interface with the Pākehā world. 
within the University Academy

This is an important feature of the model, as it does not propose that Māori be assimilated, integrated or subsumed by non-Māori into the dominant culture. Rangihau often spoke about his model likening it to a clock and identifying particular cultural concepts at different locations of the clock.

The placement of the cultural concepts in the model reflects primary relationships between the concepts. For example: the first layer/tier from the centre outward is AROHA (love, concern for others, sympathy, charity) which emphasises the notion that whānau/hapū/iwi (extended family/clan/tribe) are committed to the survival of their kinship group/s to ensure their identity as tangata whenua (the Indigenous people of the land) for future generations.

Many whakataukī (cryptic sayings, aphorisms, or proverbs) have been developed to depict this. For example:

He kōpū tahi, he taura whiri tātou;

whiringa a nuku, whiringa a rangi, tē whatia $e$

Issue of one womb, we are woven from a rope of many strands,

woven on earth, woven in heaven, it will not break. ${ }^{13}$

The placement of the Māori world at the centre of the Rangihau model and Pākehā culture on the periphery reflects the philosophy of kaupapa Māori ideology in that teaching, research and assessment is delivered from this paradigm. For this reason, it is important to realise that this framework is central to the daily operation of Māori Studies departments in universities. It should underpin everything Māori Studies staff do every day of their lives working at their university. In so doing, they are modelling to their students, to the Māori community and to the rest of the University what it is to be Indigenous despite being from different iwi and from various corners of the Pacific.

So how do Māori Studies departments/schools/faculties find legitimacy within the academy and resist becoming the 'Other' and being pushed to the margins or the periphery? A case-study of Te Tumu, the School of Māori, Pacific and Indigenous Studies at the University of Otago, may provide some useful insight into how one Indigenous Studies School within the academy has tried to survive the pressures of neocolonialism and has achieved some measure of success in negotiating between the dominant Western academic culture of the university and the maintenance of Indigenous components inherent in kaupapa Māori ideology to retain its 
identity and to be responsive to the Indigenous community. Furthermore, this case study will demonstrate how Te Tumu has put kaupapa Māori into effect.

\section{Case study of Te Tumu \\ Historical Background}

In 1995 Te Tumu, then known as the Department of Māori Studies, went through a rigorous review. One of the recommendations in the Review Panel Report 1995 was to appoint a professor whose role was largely to 'cleanup' the Department on all levels and to provide academic leadership. The professor used the recommendations of the Review Panel Report 1995 as a basis for change. Very soon after her arrival, she wrote a document called 'He Huarahi Hou' (A New Pathway) which was adopted by the staff in the Department as a strategy for change.

It was a strategy for both structural and academic qualitative change across seventeen portfolios. It proposed simultaneous progression across curriculum, staffing, development of a new building, professional development of staff, budget and financial management, a postgraduate studies programme, a marketing strategy to promote programmes, development of a commercial arm to generate funding, internationalisation to attract overseas students, establishment of a research unit, liaison and recruitment, assessment training, performance appraisal programme, relationship building with iwi, pastoral care, and a miscellaneous category which accommodated matters concerning the interface of Māori Studies with the rest of the University. 14

On the basis of staff responses, 'He Huarahi Hou' became the foundation document for change. Unfortunately, for the remainder of 1996, due to the limited experience and qualifications of staff in the Department, the majority of the work fell largely on the shoulders of the new professor. Some reprieve came the year later when another professor joined the Department and provided additional support.

On taking up her appointment as Foundation Chair of Māori Studies at Otago, the professor knew that she was taking on a difficult job for four reasons:

1.0 The Department did not have a good reputation at providing 'cutting edge teaching and research in the discipline, 
within the University Academy

compared with other university Māori Studies departments and was described as dysfunctional.

2.0 There was a pattern of rapidly declining EFTS 15 that suggested the department was in a crisis.

3.0 There was an exodus of people from the region, bypassing the University of Otago to learn Māori at other institutions in the North Island, including Te Wānanga o Raukawa and The University of Waikato.

4.0 The University of Otago was considered by those in the Māori world as being extremely conservative, resistant to the inclusion of Māori language and culture as subjects to be offered and unwilling to recognise the significance and importance of Treaty obligations, including establishing a relationship with Ngāi Tahu, the local tribal Māori people. ${ }^{16}$ Furthermore, Otago was described by many respected Māori academics across Aotearoa/New Zealand as a cultural desert because people were perceived as being insensitive toward Māori people and to the discipline of Māori Studies. For example, while Otago was the oldest of New Zealand's Universities, it had the youngest Māori Studies department. Many Māori also viewed its geographical isolation from and lack of representation at important Māori forums in the North Island as negative factors.

The new professor as Head of Department worked hard in her first year to establish networks within the University to assist the Department in implementing over thirty recommendations in the 1995 Review Report. She worked with a range of people to set up a transparent system of operation and to educate people in the University about how the Department intended to operate a dual system that would have enormous benefits for the University.

So what was this dual system that operates in Te Tumu? In a nutshell, it is about serving two masters simultaneously, namely, the University in terms of the core business and the indigenous world. Firstly, attention must be afforded te ao Māori because Māori are the tangata whenua of Aotearoa/New Zealand. Secondly, the Pacific and Indigenous peoples should be accommodated to ensure credibility in the Indigenous world. 


\section{Observance of Māori Cultural Concepts}

Understanding Māori cultural practices and cultural obligations can be difficult for non-Māori, or even Māori staff within the academy who do not speak their own language. However, the leadership of Te Tumu went to great lengths to observe these cultural values in the workplace and to educate new staff about the efficacy of embracing a dual curriculum and observing cultural practices. It is this factor which is least understood by the University and requires a change in mindset.

Many of these cultural concepts overlap each other and have similar meanings. They are not synonyms and have distinctive features, even though they share similarities. This is part of the unique make-up of the Māori world-view where everything shares a whakapapa (genealogy). This notion of relationship between the language, people, the environment and the spiritual world is the foundation to understanding the Māori world and, therefore, Te Tumu.

The Māori world-view is holistic and cyclic, one in which every person is linked to every living thing and to the atua [ancestors of ongoing influence with power over particular domains ${ }^{17}$ ]. Māori customary concepts are interconnected through a whakapapa (genealogical structure) that links te taha wairua (spiritual aspects) and te taha kikokiko (physical aspects). The most commonly known definition of whakapapa is "genealogical table",18 which describes the relationships or connections between groups of people. However, for Māori, this definition extends beyond human relationships into connections between humans and their universe. This intricately woven whakapapa has often made defining individual customary concepts extremely difficult, as each concept is defined by its relationship with other concepts and not in isolation. It is this whakapapa between te taha wairua and te taha kikokiko that brings to life different aspects of Māori culture. ${ }^{19}$

The following are some examples of the concepts that were practised in Te Tumu to ensure that staff members were able to maintain their identity as Indigenes within the University of Otago and for those non-Māori staff to demonstrate their commitment to Māori Studies as a discipline. The articulation of these cultural concepts are critical for the academy to absorb and digest to ensure that Indigenous academics are 
within the University Academy

respected and well provided for within the university construct.

\section{Mana and Tapu}

Undisputedly, mana and tapu are two important concepts of Māori society. It is difficult to define these two concepts accurately with single word definitions. Instead, they are defined based on their relationship or whakapapa to the situation being described. They are highly complex concepts that have been seen to be synonymous with each other. Mana is often defined as 'authority, control, influence, prestige, power, and status'. ${ }^{20}$ Tapu is seen as a concept that dictated social control. Elsdon Best states that:

The system of tapu was a series of prohibitions, and its influence was very far-reaching - so much so that it entered into all activities of native life. The laws of tapu affected all crises of life - birth, marriage, sickness, death, burial, exhumation; all industries; and no person in the community was exempt from its stringent rules. To disregard those rules meant disaster to the individual; but punishment meted out to the transgressor was not inflicted by his fellow-tribesman - it was imposed by the gods. ${ }^{21}$

According to Michael Shirres, tapu is the "potentiality for power while mana is the power itself'. Everything in the world pertains to mana and tapu, although to varying degrees. Hierarchical structures in Māori society demonstrate this through the notion of ariki (paramount chief), rangatira (chief of a hapū), tūtūā (commoner) and taurekareka (slave). Understanding one's whakapapa is essential in determining status in Māori society. Therefore, mana and tapu can be inherited. An example of this is the Kingitanga (King Movement) and the accession of Kingi Tūheitia to the position upon the death of his mother, Te Arikinui Dame Te Atairangikaahu. Māori society continues to recognise inherited mana and tapu of individuals and their collective, whānau, hapū and iwi. Furthermore, mana can be acquired in leadership by the action of people. This is recognised by the actions of individuals in support of their collective groups. Mana and tapu in these instances is recognised by Māori people when they show support for these people. 
The mana and tapu principles were the source of both order and dispute in Māori society. Mana and tapu were the practical forces of the kâwai tipuna [ancestors] at work in everyday matters, and the need to defend mana and tapu against attacks by insult, excessive generosity, war or mākutu [sorcery] through $u t u$, made life turbulent at times. On the other hand, mana and tapu was the principle responsible for inspiring great hospitality and feasting, aristocratic rituals and alliances, the construction of $p \bar{a}$, and wharenui, to name a few examples. In the Māori world, virtually every activity, ceremonial or otherwise, has a link with the maintenance of and enhancement of mana and tapu. It is central to the integrity of the person and the group. Many everyday measures, threaded into the fabric of existence, are designed, consciously or otherwise, as maintainers of mana and tapu 22

To ignore the mana and tapu of individuals and their respective collectives would be seen as takahi mana (trampling on the mana) and there would be consequences that would result through these actions. Māori exert a lot of energy in respecting mana and tapu, as the consequences can often be difficult to reverse and the adverse effects on a person's reputation can damage them for life.

By following the takahi mana course, there are consequences and debts to pay in the future. It revolves around the whole notion of reciprocity. By engaging in takahi mana, people have to accept it could come back on them. That is an important point about takahi mana: at some later date something of like manner may be visited upon you unless you take the necessary action to prevent that. ${ }^{23}$

To takahi mana can cause great whakamā (shame and embarrassment). Māori avoid this concept because it can have the effect of causing a stigma on the collective. This again supports the notion that collective interests are held above individual ones. Ultimately, shame can be brought upon the collective through the actions of an individual and therefore, the collective has to take responsibility for this. Often this whakamā can be so intense that admonishment is one form of dealing with this. "Thus if you are representing a particular group, you must act in a manner that does not bring disgrace on them'. ${ }^{24}$ 
within the University Academy

\section{Aroha}

Like the English word 'love', aroha is also a widely defined term with a range of related meanings. It is seen as love, respect, care, affection, friendship, concern, hospitality and the process of giving. Many Māori people see aroha as being a core concept that affects all concepts in the Māori world (see Rangihau model).

An example of aroha is seen during the process of a hui when the manuhiri present a koha. It is an expression of goodwill towards the tangata whenua. There is the aroha or expression of sympathy and respect for the person at the time of death and for the kirimate [immediate family of deceased]. Also the aroha or regard for ones ancestral lands. There is the expression of love between a man and woman and their children and others within the kin group.

Aroha

- Is an admirable attribute that has a lasting effect;

- Is a challenge to provide good parenting;

- Conveys that the values of care, respect and affection as important;

- Failure could result in embarrassment and a dysfunctional whānau. ${ }^{25}$

There are numerous cultural concepts that relate to the expression of aroha.

\section{Tauutuutu}

Tauutuutu is more commonly known as a particular kawa (protocol) practised on the marae. This is peculiar to the formal speech delivery where there is an interchange between tangata whenua (hosts) and manuhiri (visitors) on a one to one basis. However, the base word of 'tauutuutu' is 'utu', which is an important concept to Māori as it relates to their social relationships. 'Utu was concerned with the maintenance of relationships and balance within Māori society. It acted as an effective form of social control governing people's behaviour in relation to each other'. 26

Utu is often defined as 'revenge'. However, this is only one aspect of its fuller meaning. As revenge, it is usually applied as a result of an incident where the mana and tapu of a person 
was challenged. In this case, retribution is sought to regain and restore a balance with the initial offended party. However, balance is often temporary, as each party continually seeks utu until an agreement is reached between them when the matter is considered ea (balanced). More often than not, the initial hara (wrong) is so insignificant that it is overshadowed by the later events of $u t u .{ }^{27}$

Although this concept, as described above, can be viewed in a negative way as seeking vengeance, utu actually pervaded both the negative and positive aspects of Māori life by requiring some sort of response to any given situation. ${ }^{28}$ Thus, utu is also defined as: 'Return for anything; satisfaction, ransom, reward, price, reply, make response'. ${ }^{29}$ As utu is considered a cultural concept that affects our social relationships in Māori society, it is still a concept that is practised by Māori people in contemporary society, and particularly in the manifestation of koha in our work and participation in the Māori world.

A major component of utu was gift exchange. Social dealings were maintained through reciprocal exchanges of kindness and hospitality as well as the exchange of tangible goods and services. There was a continuing obligation to give, return and receive, not only between individuals and groups, but also between human beings and the natural world. 30

As noted above, maintenance of social relationships in Māori society requires interaction and reciprocal exchanges as part of a larger obligation to our culture. This is due to the relationship that the concept has with mana (refers to authority, power, prestige etc).

Often individuals and groups were prepared to make personal sacrifices to uphold their mana because the mantle of mana embraces the people, and when worn demands and provides far more than just prestige and status. To fail to give or receive $u t u$ diminished the mana of both parties and placed the relation in jeopardy. So too did giving in excess, since it made it difficult for the receiver to make a worthy return. To leave any matter as it stood meant that one could be seen as lacking mana. ${ }^{31}$

In Māori society there is always an expectation that reciprocity will be met and bettered upon return of such exchange to ensure that mana is maintained between our social relationships. 'Failure to deliver soon acquired notoriety and could result in exclusion from future deals and the loss of desired goods and services'. 32 
within the University Academy

\section{Kanohi kitea}

Kanohi kitea literally means 'a seen face' and relates to social interaction between Māori communities. It is connected to tauutuutu, as there is an expectation that parties reciprocate by attending important events irrespective of the event. For example, tangihanga is considered the most important event to attend. "The importance of the tangihanga and its central place in marae custom is reflected in the fact that it takes precedence over any other gathering on the marae'. ${ }^{33}$ Remembering and acknowledging the dead is an important part of Māori culture. It is part of our social interaction irrespective of the nature of the event. Therefore, not to be seen at such events is not to acknowledge the mana of the grieving whānau, hapū and iwi. Furthermore, representation at such events often requires more than just individuals, as collectively each Māori person represents not only the institution that they belong to but also their personal whakapapa (genealogy). This is important in respect to utu, as failure to participate with our communities again can result in being excluded from participation at other levels.

Kanohi kitea is related to 'te matemate-a-one'. The major difference is that te matemate-a-one is a feeling generated from within the individual. Kanohi kitea is a compulsion generated by the expectations of the kin and in some instances the social group. The term connotes obligations on the individual to be present during important life crises, for example tangihanga and marriage and to participate in activities that fall into that category under the colloquialism, "many hands make light work"...

Kanohi kitea:

- Requires people to take action to determine their own destiny;

- Is the group influence on identity and kinship obligations;

- Reflects the importance of maintaining kinship links;

- Means one must be able to deal with the criticisms if they do not present themselves at home;

- Could cause anger, frustration and violence. ${ }^{34}$

\section{Manaaki}


Manaaki is an extremely important concept in Māori society. The base word of manaaki is mana and the demonstration of manaaki is a social institution of Māori society.

Manaaki stands for a sense of reciprocity, of giving and receiving. In classical Māori society, this could only be achieved by residing together, and hence manaaki in effect created a sense of kinship. Important expressions of manaaki within kin group included the manaaki shown by the people to its rangatira [leader]. Such support enhanced the mana of the leaders and, as a consequence, of the group itself. Conversely, the rangatira showed manaaki for the people, and thereby secured their loyalty and love. Such double-sided manaaki strengthened the kin group itself, both internally and in relation to other groups. ${ }^{35}$

The marae and the protocols associated with the marae are designed physically and metaphorically to practise the important social institution of manaaki. For example, the shape, layout and design of the wharenui (main meeting house) is representative of an ancestor: the long barge boards that run down from the koruru (carved face located at the apex of the house) are the maihi that represent the arms of the ancestor outstretched to invite all the visitors inside. Similarly, inside the house, the interior layout specifically has a side for the hosts (tara iti) and a side for the visitors (tara whānui). Upon entering the house from the door, the left hand side is the tara iti and the right is the tara whānui. The latter side has the majority of the house in order to give visitors more room and comfort during their stay. This is also practised in the dining hall where it is a cultural imperative to ensure that all visitors are given the best food and hospitality. Visitors are quick to note when they have not been treated with proper respect and hospitality, especially in respect to comfort and food. Failure to do so can often brand a host with the following proverbs: 'He tangata takahi manuhiri, he marae puehu - If one tramples or fails to respect guests the marae becomes dusty'. ${ }^{36}$ In essence this proverb reminds us that if we do not care for our manuhiri then we will sever our relationship with them and it will consequently mean that our mana will become diminished because we will gain a reputation for being inhospitable. 

within the University Academy

Manaaki

- Is a challenge and reminder to always host visitors appropriately;

- Signifies that giving your best is important;

- Implies that failure to host could result in embarrassment ${ }^{37}$

\section{Whanaungatanga}

This concept is tied to kinship structures and social relationships. From the base word whānau (family, including extended family), whanaungatanga describes the relationship Māori have with their kin and how they practise their interaction with their kin. The word whānau today has extended to include modern Māori social organisations, such as school groups, kapa haka (performing arts groups), political movements, business structures, etc. Therefore, the nature of whānau has changed to be more inclusive of people who respect and share a similar kaupapa (purpose). Whether being related by genealogy or not, Māori continue to practise the concept of whanaungatanga, which embodies a love and commitment to that particular group of people. Furthermore, it is imperative for that group to protect, nurture and respond when called upon as an expression of that whanaungatanga.

Whanaungatanga deals with the practices that bond and strengthen the kinship ties of a whanau. The commitment of 'aroha' is vital to whanaungatanga and the survival of what the group sees as important. Loyalty, obligation, commitment, and inbuilt support systems made the whanau a strong stable unit. 38

Pere supports the notion that in Māori society there is an emphasis on working for the collective and not for the individual. This distinctive characteristic enforces the unity of people by encouraging loyalty, obligation and commitment as a mechanism for developing the whānau unit internally.

The concept of whanaungatanga is not restricted to relations within the iwi. The expression of this concept is illustrated in the interaction of whänau, hapu and iwi internally as one social unit or with outsiders. The manifestation of whanaungatanga internally is noted in a group's ability to draw closer together in times of happiness and sadness. Externally this concept is expressed through the acts of manaaki (to show respect or kindness to). ${ }^{39}$ 
As expressed earlier, there is a significant overlap between cultural concepts that interact with each other in the practices of Māori culture.

\section{Matemate-ā-one}

This Tūhoe concept is defined by Moorfield as 'deep affection, profound affection for one's land and people, condition or state that elicits certain cultural responses from indigenes'. ${ }^{40}$ There is a strong similarity between this concept and manaaki, whanaungatanga, whakapapa and whenua. For Tūhoe people, it is very much an essential element of their peculiar identity as an iwi. There are elements of this Tūhoe concept that are practised by Māori as a whole and generally can be seen as related to manaaki and whanaungatanga. Tied in with the notion of hospitality and kinship-based relationships is a strong obligation to ensure that the elements of this concept are never compromised or ignored. While this term is unique to Tūhoe, it reflects the practice of other iwi as well.

\section{Awhi}

Awhi is defined as 'embrace, foster and cherish'.41 It is the nurturing of people. It is similar to manaaki and whanaungatanga. However, the distinctive feature of this concept is that it can be individuals assisting other individuals. For example, it can be seen to be helping in areas of mentoring and support for an individual.

Awhi, 'hāpai' and 'tautoko' generally convey the values of care, respect and affection. They are terms that describe positive forms of action when dealing with interpersonal relationship matters. The term awhi means to physically embrace, cuddle and foster someone, while metaphorically it conveys the idea of nurturing, sheltering, protecting and caring for others...

Awhi:

- Expounds that nurturing and good parenting are critical;

- Is respect, industry and self discipline;

- Failure could result in embarrassment ${ }^{42}$ 


\section{Mahi tahi}

This concept is about collaboration, cooperation and working together as one. It embraces the concepts of awhi, manaaki and whanaungatanga. This is about unity and working together for the collective good. In Māori society, individuality is not always promoted over the collective mana of the people. Often Māori will see individuality as being whakahīh $\overline{1}$ (arrogance) and although individual achievement is not discouraged, the collective shares the achievement. It is believed that achievement in Māori society is attained through the awhi of others, including our ancestors who came before us. As part of this concept of mahi tahi, Māori people are encouraged to whakaiti (display humility) and honour the support and work of others in recognition of individual achievement. Associated with this is the negative that when an individual has erred it becomes the responsibility of the collective as well.

Māori society was largely based around collective responsibility. Individualism and individual responsibility was uncommon. If an individual wronged against another individual or kin group, the whānau and hapū of that individual would have to take responsibility for those actions ...The imposition on the whänau or hapu for taking responsibility for an individual's actions strengthened the sense of reciprocal group obligations. ${ }^{43}$

\section{Tuakana/Teina}

These terms are more commonly used to describe genealogical relationships between older and younger siblings. The tuakana (elder sibling) and teina (younger sibling) are terms that extend beyond the immediate family and embrace the extended whakapapa to cousins. Today, the term is also used with kaupapa driven whānau and work on the principle that the tuakana will be there to mentor and support the teina in the group.

\section{Tuakiri Tangata}

This concept refers to the Māori components of the total personality of the Māori learner based on the learner centred learning process. This pedagogical belief incorporates other 
concepts that are particularly important to Te Tumu. They are summarised in the following table: ${ }^{44}$

\begin{tabular}{|l|l|}
\hline Mauri & $\begin{array}{l}\text { The life force of all objects including } \\
\text { inanimate objects }\end{array}$ \\
\hline Wairua & $\begin{array}{l}\text { The spiritual relationships of the learner with } \\
\text { the world around them. This includes the various } \\
\text { levels of consciousness and the feelings that } \\
\text { drive them to certain behaviour. }\end{array}$ \\
\hline Iho Matua & $\begin{array}{l}\text { The spiritual manifestation of the learner } \\
\text { couched in a specific framework. It is the deepest } \\
\text { of spiritual relationships that a learner has with } \\
\text { people, things and the total environment in } \\
\text { which they live. }\end{array}$ \\
\hline Tinana & $\begin{array}{l}\text { The physical well-being of the learner. } \\
\text { Ngākau } \\
\text { feel various emotions. }\end{array}$ \\
\hline Whatumanawa & $\begin{array}{l}\text { Is concerned with processing the deepest of } \\
\text { emotions that actually govern the learner's } \\
\text { course in life in making decisions about various } \\
\text { circumstances or conditions such as love and } \\
\text { grief. }\end{array}$ \\
\hline Hinengaro & The mental capacity of the learner \\
\hline Pümanawa & $\begin{array}{l}\text { The learner's potential } \\
\text { Auaha }\end{array}$ \\
\hline $\begin{array}{l}\text { The creative side of a learner and what they } \\
\text { caple of }\end{array}$
\end{tabular}

\section{Te Tiriti o Waitangi}

The Treaty of Waitangi was signed in 1840 and the subsequent policies that have been based on the principles of Te Tiriti o Waitangi are integral to identity as Māori in Aotearoa/New Zealand. Te Tiriti o Waitangi, under Article 2, expresses the right to practise our tino rangatiratanga (selfdetermination) over our land, environment, resources, language and other taonga. It was a concept that Te Tumu staff practised and held dear as a right as the Indigenous people of Aotearoa/New Zealand. 


\section{Implementation of Kaupapa Māori Ideology}

Te Tumu comprised an eclectic staff (academic and administrative) in that their academic interests and specialties were diverse, reflecting the curriculum offered and the research carried out. Unlike most other departments in the University of Otago, Te Tumu through its primary Māori Studies major had been a department for only 17 years at Otago (1990) and a cost centre 45 since 1997. Only one of the staff employed prior to 1996 had a $\mathrm{PhD}$, with the majority of staff having merely Bachelor degrees.

Embedded in the culture of tradition at the University of Otago is the expectation that all academics require a $\mathrm{PhD}$. It was expected that Te Tumu staff had the skills and qualifications in order to participate effectively in the wider University where the 'culture' and hegemony reflected the dominant majority. Therefore, staff were required to work simultaneously in two very different cultural frameworks; one that related to being Indigenous and living and working with Indigenous knowledge systems, and the other which was built on the historical traditions of the University. Expecting staff to be bicultural and preferably bilingual and academically qualified in order to work effectively within the University setting in an Indigenous school manifested this. Being bilingual and bicultural is not a prerequisite for University employees in other sectors of the University, but it was a necessary requirement for Te Tumu staff as it was the tool to be able to operate effectively within Te Tumu and to ensure credibility in the Māori world in particular. Again the University needs to extend their promotion and progression criteria to recognise these skills and attributes of Te Tumu staff.

\section{Curriculum Design}

Te Tumu offered a curriculum that reflected its cultural base (Kaupapa Māori Ideology) and world-view. The staff tried to deliver this curriculum in the Māori language as often as they could. But what does this mean? It means that the curriculum was centred on an Indigenous Māori world-view using the following cultural markers: 
Tribal Identity: the importance of a sense of place and belonging through genealogical ties.

Land and Landscape: the recognition of the need for respect, harmony, and balance by the people for the land and the resources it provides.

Spirituality: based on a spiritual view of and response to the natural world.

Elders: serve as a critical link to the past in the present context to ensure cultural practices and tribal knowledge remain intact for future generations.

Language: the recognition that the language contains many cultural indicators that enrich one's identity.

Indigenous Knowledge: the importance of culturally determined ways of thinking, behaving, communicating and living as Indigenous people.

Diversity: the celebration of tribal identity and a rejection of non-indigenous labels and definitions that homogenise Māori people.

Kinship Structure: based on a collaborative/shared power system within social hierarchies.

Self-determination: the recognition of the rights of Indigenous peoples to live as Indigenous people. To be healthy, Māori, Pacific and Indigenous people need access to learning their language, to education and qualifications, to employment and to have their culture valued in accordance with the Te Tiriti o Waitangi. They need to be able to be active participants in determining their own future.

Concept of time: the culture is structured to look to the past as a guide for the present and the future.

Cultural knowledge: this is viewed in a holistic framework where all aspects are interrelated.

Reciprocity: based on the view that mutual respect is the cornerstone of human relationships and between humans and the environment. 46

Furthermore, Indigenous theories were taught within the curriculum which anchored Te Tumu firmly within the academy and which gave expression to Indigenous cultural concepts and imperatives. Within Te Tumu, staff utilised Indigenous pedagogies (learning and teaching methods) that enhanced the curriculum, such as residential and/or experiential learning known as wānanga. Staff also utilised assessment techniques that aligned with Kaupapa Māori theory and ideology such as standards-based assessment, also known as criterion-based assessment. This form of 
within the University Academy

assessment required staff to provide constructive feedback to students so they could improve their own learning, therefore using assessment as a tool for better learning.

Te Tumu staff lived their culture within the academy and took the time to integrate Indigenous cultural practices within their working environment. They impressed upon their students to value the Māori language and culture and not to fall victim to the power of neo-colonialism and devalue the degrees Te Tumu offers, dismissing them as useless and not leading to employment.

Staff was also committed to succession planning and developing intellectual capacity by encouraging students to consider a career in academia that would result in the discipline of Māori Studies remaining intact within the academy for the benefit of future generations. Senior staff also mentored junior staff to help them seek promotion and progression up the scale to assume senior positions within the academy and become more active agents of change. The leadership in the School did this by providing staff without $\mathrm{PhDs}$ the resources needed to complete a $\mathrm{PhD}$, including reduced teaching loads and minimal administration, plus full payment of tuition fees. Senior staff also took on teaching at the higher levels, including supervision of theses and heavy administration workloads. These heavy workloads were sustained for ten years.

The leadership in Te Tumu staff worked hard to vie for the fiscal resources needed to have a purpose designed facility built which reflected the School's cultural heritage and identity, where staff were able to observe cultural practices and transmit this knowledge to their students according to Māori pedagogical practices. This took ten years to achieve. The facility has specific places where no shoes should be worn; there is a teaching space where students sit on covered mattresses on the floor; there are spaces designed for wānanga (residential learning), including a commercial kitchen and dining area and ablutions, where students and staff can stay for a sustained period of time to deliver courses and various programmes of study.

Staff were encouraged to actively participate within their Indigenous tribal communities as individuals and as a collective. These practices of matemate-ā-one and kanohi kitea ensured their cultural competency, respectability and credibility within te ao Māori (the Māori world) was sustained. It was imperative that staff were practitioners of their culture 
as Indigenous scholars within the academy and that Indigenous communities saw them in this light. The leadership found opportunities to engage and work with Māori communities by undertaking consultancies for iwi (tribe/s) and for Māori agencies such as Te Taura Whiri i te Reo Māori (The Māori Language Commission). The senior staff also tried to create research opportunities that lined up with iwi plans. Given the relationships forged by the leadership in Te Tumu resulting in increased enrolments at both undergraduate and postgraduate levels, the leadership ensured attendance at tangihanga (funerals) associated with iwi and people who have supported Te Tumu over the years. This is an expression of tauutuutu and kanohi kitea.

\section{Research Culture}

Kaupapa Māori ideology in Te Tumu also underpinned the research culture that had been developed in the School. This meant that staff undertook research and published works to give expression to their commitment to doing research which recovers our histories, reclaims our lands and resources, restores justice and preserves our language and traditions within a culturally specific framework.

Staff were asked to observe Indigenous Research Ethics ${ }^{47}$ in their own research and promote the adoption of Indigenous theoretical research methodologies amongst postgraduate research students in undertaking their dissertations and theses. This demonstrates that Te Tumu was producing graduates who were equipped with a clear understanding of Kaupapa Māori ideology and applying this in their own scholarship.

As junior staff attained their PhDs they were mentored by senior staff to develop their skills in grant writing so they would feel confident to apply for external research funding. Given the Performance Based Research Funding (PBRF) ${ }^{48}$ environment, it is critical for staff to be research active. To assist staff to have a balanced approach to their teaching and research, Te Tumu developed a register and timeline for staff to identify their publication targets and outputs for each year.

This was the work of Te Tumu staff within the School. However, staff also did a lot of work outside the School that related to the dual function of Te Tumu staff within the academy that benefited the wider University. 


\section{Participation of Te Tumu staff and students in programmes across the University}

Te Tumu staff participated in activities across the University that demonstrated leadership in Māori, Pacific and Indigenous responsiveness. This included contributing to the Higher Education Development Centre's Staff Development and Treaty of Waitangi Education Programme, for example providing workshops or seminars (sometimes across the three campuses in Dunedin, Christchurch and Wellington) in Introduction to Māori Language, Basic Māori Language, Introduction to the Treaty of Waitangi, Advanced Treaty of Waitangi and Understanding Māori Cultural Concepts. The Dean of Te Tumu represented the Vice-Chancellor and the interests of Māori at Otago on Te Kāhui Amokura (the Māori Standing Committee on the New Zealand Vice-Chancellors' Committee). Several staff provided lectures in other departments including Geography, Surveying, Physiotherapy, Anthropology, and Gender and Women's Studies. Some of these departments depended on Te Tumu offering particular papers in Te Tumu as they were an implicit part of their fourth year or honours programme in their respective disciplines.

Te Tumu staff frequently provided co-supervision across a range of departments for postgraduate research students. This included the Departments of Zoology, History, Design, Physical Education, Anthropology, Communication Studies, Community and Family Studies, Information Science and Geography. Many Māori students from these departments requested co-supervision from staff in Te Tumu. However, there were few academic staff in other departments that $\mathrm{Te}$ Tumu students could call on to co-supervise their dissertations or theses as the reality is that there are few Māori staff employed in other departments in the University and even fewer with PhDs.

Senior staff in Te Tumu supported, and in some cases instigated, written policy such as the University's Māori Language Policy. Other universities have used this as a template for the development of their own Māori language policies. A publication called Te Reo Mãori $i$ roto $i$ Te Whare Wānanga: Using Māori in the University was also produced as a resource for staff to incorporate Māori language into their departments in the University. 
Te Tumu offered a suite of Treaty of Waitangi papers, which were considered to be 'service' papers, as they aimed at educating people about being responsive to Māori as the tangata whenua (Indigenous people of the land) in Aotearoa/New Zealand. A suite of Ngāi Tahu papers was also offered in recognition that the University is located in the south amongst the iwi, Ngāi Tahu.

Te Tumu provided an opportunity each year for students of any culture and creed to participate in a two-week cultural and promotional trip. This provided experiential learning about Māori culture by staying on marae and learning the histories and tradition of various iwi. Many international and non-Māori students came on these trips. A high value was placed on these trips as they reflected the School's commitment to the cultural concept of kanohi kitea that is highly valued amongst these communities. These Indigenous communities then felt committed to supporting the University in a variety of ways, including sending their children and grandchildren to study at Otago and asking staff in Te Tumu to participate in various activities related to either their own communities or their own families. The face-to-face connection with iwi was a much more effective way of marketing and promoting the University than a reliance on just the media.

The performing arts group in Te Tumu, namely the Te Kapa Haka o Te Tumu, performed annually for at least one of the University's graduation ceremonies. There was little understanding in the University, outside of Te Tumu, of the time commitment to compose new material relevant to the event, to rehearse and to dress in full costume with moko (body and facial art resembling the traditional designs of Māori tattoo) for these performances. This group also performed throughout the year for various occasions, including for visiting delegations from overseas to the University and during Orientation Week for International Students. Staff and students participated in these activities because of their commitment to the cultural philosophy of Te Tumu. However, little recognition was received from the University for their participation in these activities.

These activities demonstrated a commitment and ability by Te Tumu staff to support and advance responsiveness to Māori across the University and at various levels within the University. The collective commitment was manifested through the work of staff with various sectors of the University, with iwi and amongst other Indigenous communities nationally and 
within the University Academy

internationally. Te Tumu had developed extremely impressive links within these communities that were an asset to the University and this should not be overlooked. Again, these activities probably mirror the experiences of other Māori Studies departments/schools/faculties at other universities. These activities contribute enormously to the advancement of Māori as the Indigenous people of Aotearoa/New Zealand within the tertiary sector, as well as to the education of nonIndigenous people to an Indigenous world-view.

Without a doubt Te Tumu was for the University of Otago, as are other Māori Studies departments/schools/faculties for their respective universities, the primary centre for researching and teaching Māori knowledge because its cornerstone is te reo me ngā tikanga Māori. This is the defining feature of Māori Studies departments, schools and faculties. It distinguishes them from other departments or research centres that may teach or research Māori perspectives on aspects of Māori society. University Māori Studies departments should be intellectual powerhouses for the dissemination and preservation of Māori language and culture, and for the delivery of Article Two Treaty of Waitangi obligations for the Crown. It is from this position that universities should take their lead in recognising the special status of these centres within the academy. Not to do so will be perilous for Māori Studies in the short term and for the university in the long term, given the changing Māori/Pacific demographic profile.

The Māori population is projected to rise from 15 percent of the total population in 2001 to 17 percent in 2021 . Furthermore, it is projected that in 50 years time, Māori along with Pacific students will form the majority of students in both primary and secondary schooling sectors, and will make up nearly half of tertiary students in this country. ${ }^{49}$ The real question is, without the leadership and support of Māori Studies Departments, will universities be able to provide appropriately for this rich cultural demographic milieu?

Universities need to find ways to recognise Māori Studies departments'/schools'/faculties' significant contributions to their university in the promotion, marketing and advancement of Māori at their universities and beyond. With regard to Te Tumu at the University of Otago, most of these activities were mainly funded from the School's own budget allocation generated from EFTS. Te Tumu would like to have seen the University of Otago allocate particular funds from the central administration to support the work done for the benefit of the 
whole university. This seemed a fair and reasonable expectation and would reflect the cultural concept of tauutuutu (reciprocity).

Against all odds, including institutional obstacles, Te Tumu emerged over a ten-year period as a strong and healthy School ${ }^{50}$ within the Humanities, showing leadership in being responsive to Māori across the wider University. The relative success of the School can be attributed to a number of factors:

1. To the vision and sustained hard work of the staff in Te Tumu and, in particular, its leadership.

2. To the network of non-Indigenous staff established over a long period at various levels of influence within the University who appeared to recognise and respect the significance of constitutional bi-culturalism in Aotearoa/New Zealand created by $\mathrm{Te}$ Tiriti $\mathrm{o}$ Waitangi.

3. To the students who chose to study in Te Tumu.

4. To the support of Māori tribes and communities, particularly in the North Island who chose to send their children and grandchildren to Te Tumu for their tertiary education.

5. To the families of the staff in Te Tumu for their support in a range of ways that allowed the staff to

participate actively in the development of the School.

6. To the mentors of the leadership in the School who are repositories of Indigenous knowledge and provided support to the School in a variety of ways.

These factors all contributed to the development of $\mathrm{Te}$ Tumu and will need to continue for its ongoing development and success at the University of Otago. The Review Panel Report of Te Tumu 2002 articulated the transformation of the School since the 1995 Review. It is extremely flattering of the School, its leadership and staff, and its systems and processes. ${ }^{51}$

"I wish you wouldn't sneeze so," said the Dormouse, who was sitting next to her. "I can't help it," said Alice meekly; "I'm growing." "You have no right to grow here," said the Dormouse. "Don't talk nonsense," said Alice more boldly, "you know you're growing too." 52

Like Alice, Te Tumu is growing. There is a passion here, a dynamic striving for recognition and excellence which deserves nurturing and admiration. 53

The Review Panel applauds and acknowledges the creation of transparent and clearly articulated structures and 
within the University Academy

processes since the last Departmental Review in 1995. The School now has a clearly defined and well-expressed vision, created with input from all levels of Te Tumu's personnel. The Panel members commend the consultative nature of management, with information and opportunities for staff training and development clearly presented to all.

The Panel heard repeatedly that Te Tumu had been identified as a model of best practice with regard to strategic planning. Te Tumu's goals, objectives and plans are clearly consistent with the Division's Strategic Plan, the University of Otago's Charter, Strategic Directions to 2005, Teaching and Learning Plan and the Research Management Plan and again was held up as an exemplary model.

While the Panel acknowledges the enormous commitment made by the members of the Senior Management Team (at Te Tumu), we are concerned about their excessive workloads. We commend their motivation and commitment to the vision of a strong, well-managed school and realize that these workloads will by necessity remain high until junior staff members become involved in higher level. 54

Panel members applaud what has been identified as the exemplary practice of financial management within Te Tumu. Financial processes and procedures are transparent.

The School leadership is strong, professional and visionary. The Panel acknowledges the extremely difficult task of managing a School of Māori Studies that embodies a kaupapa Māori paradigm whilst existing, and potentially flourishing, within a traditional university structure. 55

Te Tumu has established an outstanding academic reputation throughout the University, as attested by more than 40 written submissions to the Panel.

We encourage Te Tumu to continue to broker and foster involvement with Ngāi Tahu and other iwi in pursuit of, and in enrichment of, its vision. 56

Te Tumu boasts the country's best programme in te reo. The appointment of Professor John Moorfield gave the School's language programme the leadership of one of the country's most eminent scholars. ${ }^{57}$

Recognition needed from the Academy

There is a constitutional responsibility created by the signing of Te Tiriti o Waitangi, known as The Treaty of Waitangi, upon New Zealanders and extending to government departments and agents of the Crown, to provide for Māori as 
the other Treaty partner. This includes universities, given that the Crown funds them.

Historically ..., universities have enjoyed positions of elitism, as their academics and researchers ran rampant through Maori communities, selecting certain information, critiquing and analysing, writing about Maori from their own world-views and perspectives. However, the recent arrival of Maori academics in traditional university contexts and the development of tertiary indigenous institutions in New Zealand has signalled a clear challenge to academic communities that the socially constructed hierarchical knowledge categorisation and belief systems that reside within University contexts, can no longer be taken for granted as being the only valid knowledge systems. The very idea about knowledge, the ethics, morality and processes associated with information collection, the ways in which knowledge is transmitted, presented and represented, and even "what counts as knowledge" are all processes that are currently being struggled over and contested. 58

Pierre Bourdieu's theory of the social field emphasizes how social classes, especially the ruling and intellectual classes, preserve their social privileges across generations despite the myth that contemporary society boasts equality of opportunity and high social mobility achieved through education. ${ }^{59}$

Once a system of mechanisms has been constituted capable of objectively ensuring the reproduction of the established order by its own motion, the dominant class have only to let the system they dominate take its own course in order to exercise their domination. 60

Arguably, the university can be seen as a social construct of the dominant society. Following Bourdieu's theory, Indigenous scholars and Indigenous centres, such as Māori Studies within the university, are inevitably marginalized or excluded from participating equitably because they pose a threat to the intellectual and ruling class. This is because Indigenous scholars challenge the intellectual frontier of what constitutes knowledge within the academy and constantly challenge the university for resources to be able to participate equitably within the academy as well as seeking new systems, policies and procedures which embrace the needs and aspirations of different ethnic and minority groups.

Unfortunately, like other Indigenous peoples working within the academy globally, one of the biggest frustrations for Te Tumu staff, and in particular the leadership, was that 
within the University Academy

despite the successful growth and meteoric development, staff continued to feel that they had to constantly fight for recognition of their unique status and the right to be different and to behave and function as Indigenous people in an Indigenous Department/School within the university environment. Furthermore, they had to resist the constant pressure to conform to the 'culture' of the university and the dominant majority.

The smart thing for universities to do would be to realize that Māori Studies departments/schools/faculties are of strategic importance to them in helping to create a friendly environment within the university in anticipation of the demographic change in student representation. Furthermore, it would be an expression of the university valuing the opinion of Indigenous staff, a strategy related to retaining them at universities. When people feel valued in the workplace, they remain there. When they do not, they look for other opportunities further afield. Can universities afford to lose such highly qualified staff to other tertiary providers or to the public sector in terms of their charters and profiles and Treaty of Waitangi obligations in accordance with Government policy?

The university academy needs to recognise that there is a paucity of suitably qualified Indigenous staff with $\mathrm{PhDs}$, cultural competence and authenticity in the discipline of Māori studies. Universities need to provide incentives to retain these staff within their institutions. Universities must also realize that to lose qualified Indigenous staff from within the academy will send the message through the Māori world that they do not value or respect Indigenous knowledge and Indigenous scholars.

Without a doubt, Indigenous staff work tirelessly and strategically in educating non-Indigenous people who are key players within the institution politically in becoming advocates for Indigenous faculty, staff and students by creating structural change within the academy for the recognition of Indigenous people's rights. However, their reality, especially for the leaders, is that they spend an enormous amount of time within the academy having to constantly educate the dominant majority about Māori ways of thinking and doing things to get 'buy-in' of the importance of Māori Studies and the validity of creating space for Indigenous world views within the academy. Indigenous people globally have defined this position as 'Indigenising the academy'. Devon Abbott Mihesuah and Angela Cavendar Wilson expressed their 
frustration with this as Indigenous First Nations women in the United States:

Some of us wonder daily if we might be more useful, more productive, and more successful if we removed ourselves from the academy and continued our research, writing and scholarship in other arenas. Some of us feel as though we can only beat our heads against the wall so many times before the damage to our spirits outweighs whatever small gains we might be making within institutions that do not value our contributions. However, we recognize that this generation of Indigenous scholars is not the first to engage in such struggles. ${ }^{61}$

Indigenising the academy means to make the academy both responsive and responsible to Indigenous people's goals of self-determination and wellbeing. This requires a huge effort by Indigenous scholars to be committed to transforming the academy. Indigenous people adopt this role to ensure that the Indigenous voice is accurately represented and not simply reinvented by non-Indigenous people interpreting the Indigenous world according to the comfort zone of the dominant majority world view and cultural filters. This is a situation which plagues many Indigenous staff working within the academy and one which is more pronounced for Māori Studies staff because Māori Studies is the only place within universities where its core business involves the dissemination of knowledge which truly reflects the Indigenous people of the land.

Most Māori Studies departments have made some progress in this area by establishing networks of non-Indigenous academics and administrators in key positions in their universities. These people advocate for the rights of the Indigenous people in important forums. However, the time involved in this necessary educational exercise continues to frustrate Māori Studies staff. This time could be better spent on research and writing for publication. Māori Studies staff is in a constant struggle to try and reclaim the time spent on Indigenising the academy, to focus on advancing their research and publishing. 
within the University Academy

\section{Indigenous Scholars as Agents of Change}

There is a set of commonalities shared amongst Indigenous people situated in historically subordinated circumstances. These commonalities are associated with a broader self-determination and community agenda and the struggle for legitimacy and cultural integrity. Such commonalities bind Indigenous people globally. They are:

- $\quad$ an over-riding sense of commitment to the collective interests of the Indigenous community with which they are associated

- the relationship between academic studies and the 'real world'

- the participatory nature of the Indigenous community which includes elders as repositories of knowledge and the transmission of traditional beliefs, values, skills and customs

- the role that spirituality plays in the sense of attending to the development and well-being of the whole person

- a commitment to the survival and use of the Indigenous language

- understanding and respect for the Indigenous world-view

- traditional ways of constructing, organizing and using knowledge, that is Indigenous epistemologies or ways of knowing. ${ }^{62}$

As a critical mass of Indigenous scholars grows globally, we need to ensure that the task of 'Indigenising the academy' is shared across the global group of Indigenous scholars, which will challenge the dominant culture's 'cultural conquest' strategy. We need to provide a bigger voice in asserting our rights to live as Indigenes, to practise our beliefs and cultural traditions, to teach our knowledge and to speak our own languages in our own spaces within the academy. We need to continue leading the fight for our right to be Indigenous within the academy. In order to fulfil the central role that our disciplines should have in the institutions we work in, including the university, we need to be adequately resourced. Furthermore, we need to continue to inspire our children and teach them to value their heritage and their cultural identity and resist being assimilated, seduced and controlled by the dominant culture. In the words of bell hooks

... I add my voice to the collective call for renewal and rejuvenation in our teaching practices. Urging all of us to open our minds and hearts so that we can know 
beyond the boundaries of what is acceptable, so that we can think and rethink, so that we can create new visions, I celebrate teaching that enables transgressions - a movement against and beyond the boundaries. It is that movement which makes education the practice of freedom. ${ }^{63}$

As Indigenous scholars we need to reclaim our epistemologies, our pedagogies, our cultural imperatives and our languages. We must challenge the 'cultural conquest' mentality of mainstream education, including universities. We need to demonstrate to these institutions that we will never trade our own identity as a commodity. Our identity is not for sale! Furthermore, we need to put the academy on notice that their very existence on 'our lands' 64 requires them to recognise the status of Indigenous peoples and our rights to education, including our language and culture and, with reference to the New Zealand context, remind them of their obligations as a Treaty partner apropos of Te Tiriti o Waitangi and the Māori Language Act 1987. Furthermore, we have to resist the constant pressure to conform to the 'culture' of the university and the dominant majority.

The hope is that a deeper understanding of the dual function that Māori Studies, Pacific Studies, Native Studies and Indigenous Studies departments, schools and faculties have in universities, that of Indigenising the academy and then attending to their core business of teaching and research for publication, will soon be recognised by the general public, the New Zealand Government and governments globally and, last but not least, university administrations. There is a need for this formal recognition by all factions so that Indigenous Studies is afforded the funding it deserves. Indigenous scholars need to participate equitably within the academy alongside their peers and have parity with those who do not have the same dual function. There is a real fear that in Aotearoa/New Zealand Māori Studies will become an historical feature of the academy and become like the moa bird - extinct.

\section{Notes}

As evidenced by the attempt of The University of Waikato to subsume Te Tari Māori into the School of Education in the late 1990s.

2 The Treaty of Waitangi is the founding document of Aotearoa/New Zealand. It was established as a partnership between the British Crown and Māori as the Indigenous people. It was signed on the 6 February 1840 and has been 
within the University Academy

the focus of controversy ever since. This has stemmed from the fact that two versions of the Treaty were produced. The Māori text, which was signed by both Māori and the Crown, was translated from the English text by a non-Indigenous missionary. However, the translation was not at all a correct interpretation of the English text. It is the English text that has been used by the Crown as the definitive version and this is still contested by Māori.

3 Kaupapa Māori refers to a culturally specific framework. It is located in te ao Māori (the Māori world) and reflects the relationship Māori have to the land and the environment, to Māori socialisation patterns and cultural nuances and to Māori identity.

4 Te Tumu, the School of Māori, Pacific and Indigenous Studies, at the University of Otago will be the case-study as at the time this paper was written the author was foundation Professor and Dean of Te Tumu.

5 S. Webster, Patrons of Māori Culture - Power, Theory, and Ideology in the Mãori Renaissance, Dunedin, 1998, p. 157.

6 T. M. Ka'ai, 'Ngā Hua o te Mātauranga Māori i roto i te Whare Wānanga: The Value of Māori Studies in the University', Inaugural Professorial Lecture, University of Otago, 2000, pp. 11-12.

Ibid., p. 12.

L. Pihema, 'Tungia te ururua, kia tupu whakaritorito te tupu o te harakeke: a critical analysis of parents as first teachers', MA thesis, University of Auckland, 1993, p. 57.

9 R. R. Higgins, 'He Tānga Ngutu, He Tūhoetanga - Te Mana Motuhake o te Tã Moko Wahine: The Identity Politics of Moko Kauae', PhD Thesis, University of Otago, 2004, p. 8

10 Ibid., p. 5

11 A. Darder, Culture and Power in the Classroom: A Critical Foundation for Bicultural Education, New York, 1991.

12 P. Johnston, 'When Indigenous knowledge questions the limits: A lesson about wisdom', 2004, http://herdsa2004.curtin.edu.my/Contributions/Keynotes/KeynotePatrici aJohnston.pdf

13 J. Metge, Whānau Values, Wellington, 1995, p. 71.

14 Te Tumu, 'Tā Te Tumu Ake Arotake', Dunedin, University of Otago, Volume 1 , March 2002, p. 4.

15 EFTS is an abbreviation for Equivalent Full Time Students and a formula used by Government for funding tertiary education.

16 The 1998 Walker Report confirmed that the University was not Māori friendly.

17 Often atua are defined as deities or gods as they were instrumental in the creation of the world and are still respected today. They are considered by Māori as ancestors rather than gods.

18 H. W. Williams, A Dictionary of the Maori Language. Wellington, 1971, p. 259.

19 T. M. Ka‘ai, \& R. Higgins, 'Te ao Māori - Māori world-view', in T.M. Ka‘ai, J.C. Moorfield, M.P.J. Reilly, \& S. Mosley. (eds.) $\mathrm{Ki}$ Te Whaiao: An Introduction to Māori Culture and Society. Auckland, 2004, p. 13

20 H. W. Williams, p. 172.

21 E. Best, Maori Religion and Mythology, Wellington, 1982, pp. 89-90.

22 Ministry of Justice, He Hīnātore ki te Ao Mãori A Glimpse into the Mãori World Māori Perspectives on Justice, Wellington, 2001, p. 55.

23 Ibid., p. 177

24 Ibid., p. 185

Te Kaharoa, vol. 1, 2008, ISSN 1178-6035 
Ibid., p. 151

Ibid., p. 167

T. Ka'ai \& R. Higgins, p. 18.

Ministry of Justice, He Hinātore ki te Ao Mãori A Glimpse into the Mãori World Mãori Perspectives on Justice, p. 67.

H. W. Williams, p. 471.

Ministry of Justice, He Hīnātore ki te Ao Māori A Glimpse into the Mãori World Mãori Perspectives on Justice, p. 69.

Ibid., p. 68.

Ibid., p. 71.

T. M. Ka‘ai, \& R. Higgins, p. 90.

Ministry of Justice, He Hinātore ki te Ao Mãori A Glimpse into the Mãori World Mãori Perspectives on Justice, p. 160

35 M. Reilly, 'Whanaungatanga - Kinship', in T.M. Ka'ai, J.C. Moorfield, M.P.J. Reilly, \& S. Mosley. (eds.) Ki Te Whaiao: An Introduction to Māori Culture and Society. Auckland, 2004, p. 68

36 S.M. Mead, \& Grove, Ngā Pēpeha a ngā Tīpuna. Wellington, 2001 (1991), p. 78.

37 Ministry of Justice, He Hīnātore ki te Ao Māori A Glimpse into the Māori World Mãori Perspectives on Justice, p. 166.

38 R. Pere, Ako: Concepts and Learning in Maori Tradition, Hamilton, University of Waikato, 1982, p. 23

R. R. Higgins, 2004, p. 331

www.maoridictionary.co.nz.

H. W. Williams, p. 471 , p. 25.

Ministry of Justice, He Hīnātore ki te Ao Mãori A Glimpse into the Mãori World Mãori Perspectives on Justice, p. 152.

Ibid., pp. $40-1$

44 T. M. Ka'ai, 2004 , p. 210

45 A cost centre means that the Department is allocated a budget of their own to manage.

46 Adapted from T. M. Ka'ai, \& R. Higgins, pp. 23-4

47 Indigenous Research Ethics consist of a set of actions driven by cultural concepts, principles and values inherent in the Indigenous world-view which guide the researcher when undertaking research.

48 Performance based Research Funding refers to the Government system of funding the Tertiary Education sector.

49 N. First, N. \& T. Davies, 19 April 2004, New Zealand Qualifications Authority Environmental Scan to 2010 unpublished paper prepared for the Qualifications Authority Board for 6 May 2004 meeting.

50 In 1995, the then Department of Màori Studies experienced a decline in EFTS to 136 and staff were anxious that this would become a trend. A combination of new leadership and commitment by staff to turn things around has seen the pattern reversed to one of consolidated growth with EFTS recorded in 2006 at 233.61.

51 The 2002 Review Panel Report stated: 'The only area in which we thought the School might undertake further work was in articulating its policy on kaupapa Mãori ...Such a policy might have relevance to other parts of the University' (University of Otago, 2002: 23). This report provides a comprehensive explanation of kaupapa Māori and it is apparent that the Office of the Vice Chancellor is one area where an understanding of this policy is extremely relevant in order for Te Tumu to continue to exist and flourish at the University of Otago.

Te Kaharoa, vol. 1, 2008, ISSN 1178-6035 
within the University Academy

52 University of Otago. 2002. 'Report of the Panel Appointed to Review Te Tumu 9-12 April, 2002'. Dunedin: University of Otago, p. 8.

53 Ibid., p. 9.

Ibid., p. 10.

Ibid., pp. 11-12

Ibid., pp. 11-13.

Ibid., p. 20.

P. Johnson, pp. 3-4

P. Bourdieu, Outline of a Theory of Practice, Cambridge, 1977.

Ibid., p. 190

61 D. Mihesuah, \& A. Cavendar. (eds.), Indigenizing the Academy-Transforming Scholarship and Empowering Communities, Lincoln and London, 2004, pp. 6-7.

62 T. M. Ka'ai, 2000, pp. 12-21.

63 B. Hooks, Teaching to Transgress - Education as the Practice of Freedom, New York, 1994, p. 12.

64 As Indigenes our identity is sourced to our lands.

Te Kaharoa, vol. 1, 2008, ISSN 1178-6035 